\section{LUPUS SCIENCE\& MEDICINE}

\title{
In search of an antibody specificity highly predictive of congenital heart block
}

\author{
Peter M Izmirly, Amit Saxena
}

To cite: Izmirly PM, Saxena A. In search of an antibody specificity highly predictive of congenital heart block. Lupus Science \& Medicine 2016;3:e000154. doi:10.1136/lupus-2016000154

Received 29 March 2016 Accepted 3 April 2016

\section{Linked}

- http://dx.doi.org/10.1136/ lupus-2015-000129

\section{CrossMark}

Division of Rheumatology, Department of Medicine, New York University School of Medicine, New York, New York, USA

Correspondence to Dr Peter M Izmirly; Peter.Izmirly@nyumc.org
Since the relationship of maternal autoimmunity and congenital heart block (CHB) was initially described in the late 1970s, investigators have attempted to identify additional factors associated with its development. ${ }^{1-4}$ Detection of CHB in the absence of cardiac structural abnormalities predicts the presence of maternal autoantibody responses against the ribonucleoproteins SSA/Ro and $\mathrm{SSB} / \mathrm{La}$ in $>85 \%$ of cases. ${ }^{5} \mathrm{CHB}$ is associated with considerable morbidity and mortality, with a $17.5 \%$ case fatality rate and approximately $70 \%$ requiring permanent pacemaker placement. $^{6}$ Sustained reversal of thirddegree CHB has never been achieved and to date there is no approved medication for treatment or prevention of this disease. Recognising those mothers at increased risk of CHB in an offspring would provide insights into the pathogenesis of disease and help prioritise allocation of screening resources, including intense echocardiographic monitoring.

In a recent publication in Lupus Science and Medicine, Tonello et al sought to identify maternal autoantibody profiles conferring high risk for $\mathrm{CHB}^{7}$ Importantly, all serological evaluations were done during the pregnancies. The authors report a 'prospective' study with inclusion of 81 consecutive pregnant patients positive for anti-SSA/Ro \pm anti-SSB/La antibodies enrolled at the outpatient clinic of the Rheumatology Unit of the University of Padova Medical Center. The authors report a surprisingly high occurrence rate of $\mathrm{CHB}$ at $19.8 \%$. In contrast, many other studies have prospectively monitored anti-SSA/Ro patients during pregnancy and documented a rate of only $1 \%-2 \% .^{8-12}$ Additionally, in mothers with a previously affected CHB child, recurrence rates in retrospective studies have been reported at approximately $17 \%-18 \%,{ }^{13-16}$ a rate confirmed in two prospective studies. ${ }^{17}{ }^{18}$ Even if the authors remove the one recurrent $\mathrm{CHB}$ in their study, the occurrence rate would still be extremely high. In the discussion of the paper, the authors acknowledge that 13 $(81.3 \%)$ of the 16 cases of CHB were referred from different rheumatology centres in Italy. Although not explicitly stated by the authors, perhaps these pregnancies were referred at the time $\mathrm{CHB}$ was detected. If this is correct, then what is unknown is the denominator of all anti-SSA/Ro positive pregnant women followed at these referring institutions. Thus, the occurrence rate of $\mathrm{CHB}$ at $19.8 \%$ is misleading. The high rate of $\mathrm{CHB}$ reported in the paper may raise undue concern in counselling women with anti-SSA/Ro antibodies facing pregnancy. Although the authors state that reporting on the epidemiology of CHB was not their explicit goal, if any mothers were identified to have anti-SSA/Ro simply on the basis of having a child with CHB, this is not a prospective study and may explain the finding that asymptomatic mothers appear to be at higher risk of developing CHB. This may also distort the predictive value of the antibody specificities reported.

While the inclusion criterion for the study by Tonello et al was the presence of antiSSA/Ro antibodies, based on their figure 1, the titres (particularly anti-Ro60) appear quite low. ${ }^{7}$ It is already well known that CHB more frequently develops in mothers with high titre antibodies. ${ }^{19}$ Inclusion of mothers with low titre reactivities and thus at decreased risk of disease development is a limitation. To incrementally advance the field beyond what is already known, it would be important to enrol at the very least only women with high titre antibodies during the pregnancy under study.

Many previous studies, several with larger numbers, have addressed the identification of a high CHB risk profile. ${ }^{20-24}$ Conclusions have been varied depending on the method of antibody testing and/or design of the 
study. There has been particular excitement regarding the autoantibody response against the p200 epitope of Ro52 as a candidate biomarker conferring an increased CHB risk. ${ }^{22}{ }^{24}$ Reed et al assessed umbilical blood and matched maternal sera from pregnancies of both CHB affected and unaffected siblings for reactivities against Ro60 (native antigen), full-length Ro52 (recombinant antigen), p200Ro52 and La48 (recombinant antigen). ${ }^{21}$ The authors concluded that reactivity to p200 does not confer an added risk to fetal conduction defects over full-length Ro52 or Ro60 autoantibodies. Mothers who may never be at risk for having an affected child have lower anti-Ro60 titres and may require less stringent echocardiographic monitoring compared with women with high titre autoantibodies. Unfortunately they could not identify a profile that predicted recurrent $\mathrm{CHB} .{ }^{21}$

Clearly, as Tonello points out we need to better predict woman at the greatest risk for the development of CHB in an offspring, but we are not there yet. Antibody profiling should focus on evaluation of those mothers with high titre anti-SSA/Ro antibodies. Perhaps even more importantly we may have to accept that even the highest risk profile is not the answer but begin a more intense search for fetal factors.

\section{Competing interests None declared.}

Provenance and peer review Commissioned; internally peer reviewed.

Open Access This is an Open Access article distributed in accordance with the Creative Commons Attribution Non Commercial (CC BY-NC 4.0) license, which permits others to distribute, remix, adapt, build upon this work noncommercially, and license their derivative works on different terms, provided the original work is properly cited and the use is non-commercial. See: http:// creativecommons.org/licenses/by-nc/4.0/

\section{REFERENCES}

1. Scott JS, Maddison PJ, Taylor PV, et al. Connective-tissue disease, antibodies to ribonucleoprotein, and congenital heart block. $N$ Engl J Med 1983;309:209-12.

2. Reed BR, Lee LA, Harmon C, et al. Autoantibodies to SS-A/Ro in infants with congenital heart block. J Pediatr 1983;103:889-91.

3. McCue CM, Mantakas ME, Tingelstad JB, et al. Congenital heart block in newborns of mothers with connective tissue disease. Circulation 1977:56:82-90.

4. Chameides L, Truex RC, Vetter V, et al. Association of maternal systemic lupus erythematosus with congenital complete heart block. N Engl J Med 1977;297:1204-7.

5. Jaeggi ET, Hornberger LK, Smallhorn JF, et al. Prenatal diagnosis of complete atrioventricular block associated with structural heart disease: combined experience of two tertiary care centers and review of the literature. Ultrasound Obstet Gynecol 2005;26:16-21.

6. Izmirly PM, Saxena A, Kim MY, et al. Maternal and fetal factors associated with mortality and morbidity in a multi-racial/ethnic registry of anti-SSA/Ro-associated cardiac neonatal lupus. Circulation 2011;124:1927-35.
7. Tonello M, Ruffatti A, Favaro M, et al. Maternal autoantibody profiles at risk for autoimmune congenital heart block: a prospective study in high-risk patients. Lupus Sci Med 2016;3:e000129.

8. Jaeggi ET, Silverman ED, Laskin C, et al. Prolongation of the atrioventricular conduction in fetuses exposed to maternal anti-Ro/ SSA and anti-La/SSB antibodies did not predict progressive heart block. A prospective observational study on the effects of maternal antibodies on 165 fetuses. J Am Coll Cardiol 2011;57:1487-92.

9. Friedman DM, Kim MY, Copel JA, et al. Utility of cardiac monitoring in fetuses at risk for congenital heart block: the PR Interval and Dexamethasone Evaluation (PRIDE) prospective study. Circulation 2008;117:485-93.

10. Costedoat-Chalumeau N, Amoura Z, Lupoglazoff JM, et al. Outcome of pregnancies in patients with anti-SSA/Ro antibodies: a study of 165 pregnancies, with special focus on electrocardiographic variations in the children and comparison with a control group. Arthritis Rheum 2004;50:3187-94.

11. Cimaz R, Spence DL, Hornberger L, et al. Incidence and spectrum of neonatal lupus erythematosus: a prospective study of infants born to mothers with anti-Ro autoantibodies. J Pediatr 2003;142:678-83.

12. Brucato A, Frassi M, Franceschini $F$, et al. Risk of congenital complete heart block in newborns of mothers with anti-Ro/SSA antibodies detected by counterimmunoelectrophoresis: a prospective study of 100 women. Arthritis Rheum 2001;44:1832-5.

13. Izmirly PM, Costedoat-Chalumeau N, Pisoni CN, et al. Maternal use of hydroxychloroquine is associated with a reduced risk of recurrent anti-SSA/Ro-antibody-associated cardiac manifestations of neonatal lupus. Circulation 2012;126:76-82.

14. Llanos C, Izmirly PM, Katholi M, et al. Recurrence rates of cardiac manifestations associated with neonatal lupus and maternal/fetal risk factors. Arthritis Rheum 2009;60:3091-7.

15. Gladman G, Silverman ED, Yuk L, et al. Fetal echocardiographic screening of pregnancies of mothers with anti-Ro and/or anti-La antibodies. Am J Perinatol 2002;19:73-80.

16. Julkunen $\mathrm{H}$, Eronen $\mathrm{M}$. The rate of recurrence of isolated congenital heart block: a population-based study. Arthritis Rheum 2001:44:487-8.

17. Pisoni CN, Brucato A, Ruffatti A, et al. Failure of intravenous immunoglobulin to prevent congenital heart block: findings of a multicenter, prospective, observational study. Arthritis Rheum 2010;62:1147-52.

18. Friedman DM, Llanos C, Izmirly PM, et al. Evaluation of fetuses in a study of intravenous immunoglobulin as preventive therapy for congenital heart block: results of a multicenter, prospective, open-label clinical trial. Arthritis Rheum 2010;62:1138-46.

19. Jaeggi E, Laskin C, Hamilton R, et al. The importance of the level of maternal anti-Ro/SSA antibodies as a prognostic marker of the development of cardiac neonatal lupus erythematosus a prospective study of 186 antibody-exposed fetuses and infants. J Am Coll Cardiol 2010:55:2778-84.

20. Scarsi M, Radice A, Pregnolato F, et al. Anti-Ro/SSA-p200 antibodies in the prediction of congenital heart block. An Italian multicentre cross-sectional study on behalf of the 'Forum Interdisciplinare per la Ricerca nelle Malattie Autoimmuni (FIRMA) Group'. Clin Exp Rheumatol 2014;32:848-54.

21. Reed JH, Clancy RM, Lee $\mathrm{KH}$, et al. Umbilical cord blood levels of maternal antibodies reactive with p200 and full-length Ro 52 in the assessment of risk for cardiac manifestations of neonatal lupus. Arthritis Care Res (Hoboken) 2012;64:1373-81.

22. Strandberg L, Winqvist O, Sonesson SE, et al. Antibodies to amino acid 200-239 (p200) of Ro52 as serological markers for the risk of developing congenital heart block. Clin Exp Immunol 2008;154:30-7.

23. Clancy RM, Buyon JP, Ikeda K, et al. Maternal antibody responses to the 52-kd SSA/RO p200 peptide and the development of fetal conduction defects. Arthritis Rheum 2005;52:3079-86.

24. Salomonsson S, Dörner T, Theander E, et al. A serologic marker for fetal risk of congenital heart block. Arthritis Rheum 2002;46:1233-41. 